\title{
The Non-formal Education Initiative of Living Heritage Conservation for the Community towards Sustainable Development
}

\author{
Noor Azramalina Abdul Aziz ${ }^{1}$, Noor Fazamimah Mohd Ariffin ${ }^{1}$, \\ Nor Atiah Ismail ${ }^{1}$, Anuar Alias ${ }^{2}$ \\ 1 Department of Landscape Architecture, Faculty of Design and Architecture, \\ Universiti Putra Malaysia, 43400 UPM Serdang, Selangor Darul Ehsan, Malaysia. \\ 2 Department of Estate Management, Faculty of Built Environment, \\ Universiti Malaya, Jalan Universiti, Kuala Lumpur, Malaysia.
}

noorazramalina@gmail.com, fazamimah@upm.edu.my, natiah@upm.edu.my, anuar_a@um.edu.my

\begin{abstract}
Threatened by cultural modernization, many emotions and manifestations of living heritage or intangible cultural heritage $(\mathrm{ICH})$ are under crisis. The non-formal education initiative of living heritage conservation focused on preserving and passing the skills and knowledge, practices, expression, and instruments of local people on to future generations effectively. By using the literature review as an analysis method, this paper identified the best non-formal education initiative and the significance of living heritage conservation education for the community. In conclusion, quality education of living heritage conservation, not only fulfills people's needs but also helps unite and empower both local people and the community to sustain the living heritage efficiently.
\end{abstract}

Keywords: Intangible cultural heritage; Non-formal education; Public awareness; Quality education

eISSN 2398-4279 @2020 The Authors. Published for AMER ABRA cE-Bs by e-International Publishing House, Ltd., UK. This is an open access article under the CC BY-NC-ND license (http://creativecommons.org/licenses/by$n c-n d / 4.0 /$ ). Peer-review under responsibility of AMER (Association of Malaysian Environment-Behaviour 
Researchers), ABRA (Association of Behavioural Researchers on Asians) and CE-Bs (Centre for EnvironmentBehaviour Studies), Faculty of Architecture, Planning \& Surveying, Universiti Teknologi MARA, Malaysia. DOI: https://doi.org/10.21834/ajqol.v5i18.205

\subsection{Introduction}

Preservation defined as an exertion to sustain the heritage elements in both tangible and intangible elements. The tangible heritage such as buildings, landscapes, structures, sites, and communities; and the intangible elements, including oral tradition, music, and cultural activities (Coppin State University, 2002 in Hani et al., 2012; MohdBaroldin, \&Mohd Din, 2018).

In 1960, R. Williams, an influential thinker of the 20th century, recorded that culture could not be compressed as tangible products because it is continuously living and evolving. He caught the cultural heritage of the essential elements defining as the living culture of human communities, their evolution, and their continuing development. Cultural heritage as a culture of a people includes all unnecessary elements considered by a given community as compulsory components of its intrinsic identity as well as of its uniqueness and distinctiveness in comparison with all other human groups showing the very heart of its distinctive trait.

Intangible cultural heritage (ICH), showed the variety of living heritage of humanity as well as the most influential tool of cultural diversity. The primary 'constitutive factors' of ICH determine by the 'self-identification' of $\mathrm{ICH}$ as an imperative element of the cultural identity of its creators and bearers. By its connection with the cultural identity of the communities and groups, by its authenticity, and by its indissoluble relationship with human rights, ICH fixed recreation in feedback to the historical and social transformation of the communities and groups concerned (Lenzerini, 2011). Place identity connected to definition and perception believed by the people regarding their environment and the loss of identity weakens the depth of meaning, attachment, and diversity of place experience. This evident that new developments within the traditional settings in the city center transform build places and place definitions and attachments entrenched in the existing social and cultural context (Ujang, 2017).

UNESCO launched the futures of education initiative to reform how knowledge and learning can build the futures of humanity in a context of rising complexity, unpredictability, and modification in September 2019. UNESCO wants to react to challenges from climate change to growing inequalities, artificial intelligence to learning outcomes, as well as opportunities that will impact the education and well-being of future generations. Now, UNESCO asked people from around the world to contribute their perspective on what the future of knowledge can be.

The purpose of the futures of education initiative look to understand how education can build the future of humanity and the planet in 2050 and beyond. The effort is mobilizing a global debate from around the world to involve youth, educators, civil society, governments, businesses, and other stakeholders on how knowledge, teaching, and learning need to reform to address today's and tomorrow's challenges. This initiative uses the concept of futures to identify the rich diversity of ways of knowing and being around the world. 
By using literature reviews, this paper proposes to analyze the best non-formal education initiative and recognize the significance of living heritage conservation for the community toward sustainable development. This paper focused on strengthening, preserving, and passing the intangible cultural heritage that keeps it alive on to future generations in the community as the objective.

\subsection{Methodology}

This review article starts with a concept of the $\mathrm{ICH}$, the form of education, the connection between living heritage and education. Lastly, it also describes the significance of living heritage conservation education for the community toward sustainable development. This study identified the previous of the non-formal education initiative for living heritage conservation completed around the world. The limitation of this study analyzed the best non-formal education initiative truth activities and events of living heritage. At the same time, it's focused on educating a quality education of living heritage the adult and young generations in the community.

\subsection{Results}

\subsection{The Concept of Intangible Cultural Heritage}

By Article 2 the UNESCO Convention as the practices, Intangible cultural heritage is interpreted as representations, expressions, knowledge, skills, as well as the instruments, objects, artefacts and cultural spaces associated in addition to that the communities identify as part of their cultural heritage.

\begin{tabular}{|c|c|c|}
\hline 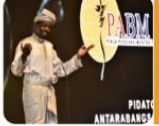 & $\begin{array}{l}\text { Oral Traditions and } \\
\text { Expressions, including } \\
\text { Language }\end{array}$ & $\begin{array}{l}\text { Encompasses an enormous variety of spoken forms including proverbs, riddles, } \\
\text { tales, nursery rhymes, legends, myths, epic songs and poems, charms, prayers, } \\
\text { chants, songs, dramatic performances and more. Used to pass on knowledge, } \\
\text { cultural and social values and collective memory and play a crucial part in } \\
\text { keeping cultures alive. }\end{array}$ \\
\hline & Performing arts & $\begin{array}{l}\text { The range from vocal and instrumental music, dance and theatre to pantomime, } \\
\text { sung verse and beyond. Included numerous cultural expressions that reflect } \\
\text { human creativity and that are also found, to some extent, in many other } \\
\text { intangible cultural heritage domains. }\end{array}$ \\
\hline & $\begin{array}{l}\text { Social practices, } \\
\text { rituals and } \\
\text { festive events }\end{array}$ & $\begin{array}{l}\text { Habitual activities that structure the lives of communities and groups and that } \\
\text { are shared by and relevant to many of their members. May help to mark the } \\
\text { passing of the seasons, events in the agricultural calendar or the stages of a } \\
\text { person's life and closely linked to a community's worldview and perception of its } \\
\text { own history and memory. From small gatherings to large-scale celebration. }\end{array}$ \\
\hline & $\begin{array}{l}\text { Knowledge and } \\
\text { practices } \\
\text { concerning nature } \\
\text { and the universe }\end{array}$ & $\begin{array}{l}\text { Included knowledge, knowhow, skills, practices and representations developed } \\
\text { by communities by interacting with the natural environment. These ways of } \\
\text { thinking about the universe are expressed through language, oral traditions, } \\
\text { feelings of attachment towards a place, memories, spirituality and worldview. }\end{array}$ \\
\hline & $\begin{array}{l}\text { Traditional } \\
\text { craftsmanship }\end{array}$ & $\begin{array}{l}\text { The most tangible manifestation of intangible cultural heritage. Rather than } \\
\text { focusing on preserving craft objects, safeguarding attempts should instead } \\
\text { concentrate on encouraging artisans to continue to produce craft and to pass } \\
\text { their skills and knowledge onto others, particularly within their own communities. }\end{array}$ \\
\hline
\end{tabular}


Figure 1: Five broads 'domains' in intangible cultural heritage.

(Source: UNESCO, 2003)

The transmitted of this heritage from generation to generation is continually renewed by communities and groups in feedback to their environment, their interaction with nature and history. It also provides them with a sense of identity and continuity, thus promoting respect for cultural diversity and human creativity. In figure 1, UNESCO's 2003 Convention for the Safeguarding of the Intangible Cultural Heritage proposes five broads 'domains' in which $\mathrm{ICH}$ manifested.

If Intangible cultural heritage not raised in the community, it has risks becoming disappeared forever or freezes as a practice belonging to the past. It's important to strengthen the intangible cultural heritage keeps it alive, preserving and passing this heritage on to future generations, and while accepting for it to transform and conform in any situation. The effective effort of safeguarding $\mathrm{ICH}$ to sustainable development gives significance in economic, social, and environment while also it was contributing to peace and security. Transmitted living heritage or $\mathrm{ICH}$ practices using quality education is the most efficient tool for local people and the community.

\subsection{Culture 2030 Agenda}

The key priority has been identified as an, in particular, aim to investigate the role of intangible cultural heritage in expanding education for sustainable development in quality education as a sustainable development goal number 4 (SGD 4). Figure 2 represented the thematic indicators divided into four categories in Culture 2030 Agenda; a) environment and resilience, b) prosperity and livelihoods, c) knowledge and skills, and d) inclusion and participation (UNESCO, 2019).

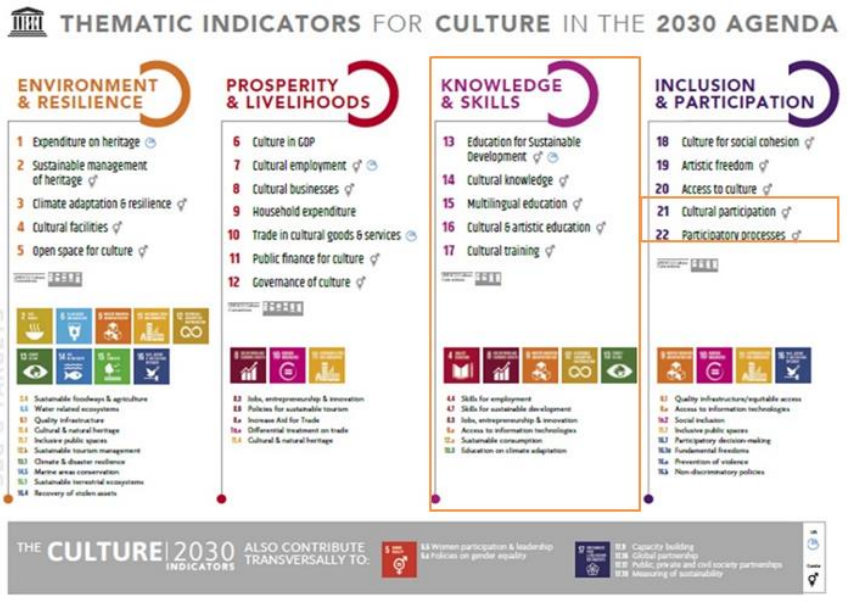

Figure 2: The thematic indicators for culture in the 2030 Agenda.

(Source: UNESCO, 2019) 
The category of knowledge, skills, and participation was focuses on this study. The sustainable development goals number 4 (quality education), 8 (decent work and economic growth), 9 (industry, innovation, and infrastructure), 12 (responsible consumption and production), 13 (climate action) and 16 (peace, justice, and strong institutions) targeted in the living heritage conservation education for the community.

\subsection{The form of education}

In this study, the form of education more focus in Non-formal education to create the quality education of Community-based education for Living Heritage Conservation on giving awareness and special knowledge to community participated and volunteer in the management and conservation of any living heritage conservation. In some cases, it is also structured according to educational and training arrangements, but more flexible. It usually takes place in community-based settings, the workplace and through the activities of civil society organizations. The Criteria for the analysis of the forms of education was summarized in Table 1.

Table 1: Criteria for the analysis of the forms of education.

\begin{tabular}{|c|c|c|c|}
\hline $\begin{array}{l}\text { Analysis } \\
\text { criteria }\end{array}$ & $\begin{array}{l}\text { Formal } \\
\text { education }\end{array}$ & $\begin{array}{l}\text { Non-formal } \\
\text { education }\end{array}$ & $\begin{array}{l}\text { Informal } \\
\text { education }\end{array}$ \\
\hline Contents & $\begin{array}{l}\text { Systematized } \\
\text { knowledge }\end{array}$ & Special knowledge & $\begin{array}{l}\text { Multidisciplinary } \\
\text { disciplines information }\end{array}$ \\
\hline Type of influence & $\begin{array}{l}\text { - Formative educative; } \\
\text { - Systematized; } \\
\text { - Organized; } \\
\text { - Reported to goals. }\end{array}$ & $\begin{array}{l}\text { - Formative educative } \\
\text { influences correlated with } \\
\text { those from the extra } \\
\text { school environment. }\end{array}$ & $\begin{array}{l}\text { - Spontaneous; } \\
\text { - Diffuse; } \\
\text { - Heterogeneous; } \\
\text { - Pedagogically } \\
\text { unorganized; } \\
\text { - Pedagogically } \\
\text { unprepared; } \\
\text { - Decided on the spot; } \\
\text { - Incidental; } \\
\text { - Non-systematized; } \\
\text { - unreported to goals of } \\
\text { short duration. }\end{array}$ \\
\hline Effects & Projected, positive & Projected, positive & $\begin{array}{l}\text { Non-projected, positive } \\
\text { and negative }\end{array}$ \\
\hline Way of achieving & Direct & Direct & Individual, implicit \\
\hline Involved factors & $\begin{array}{l}\text { Realized in specialized } \\
\text { Institutions (schools of } \\
\text { different types). }\end{array}$ & $\begin{array}{l}\text { Realized outside the } \\
\text { school institution }\end{array}$ & $\begin{array}{l}\text { The most significant } \\
\text { messages are those } \\
\text { issued by media } \\
\text { (newspapers, } \\
\text { magazines, posters, } \\
\text { CDs) }\end{array}$ \\
\hline Categories of activities & - formal activities & - outside class & - Relaxing activities; \\
\hline
\end{tabular}




\begin{tabular}{|c|l|l|l|}
\hline & & \multicolumn{1}{|c|}{$\begin{array}{c}\text { (Olympics, } \\
\text { thematic circles); } \\
\text { - outside school } \\
\text { (performances, } \\
\text { trips, conferences - } \\
\text { other activities); } \\
\text { - after getting a job } \\
\text { (lifelong learning } \\
\text { activities) }\end{array}$} & $\begin{array}{l}\text { - Everyday training } \\
\text { situations. }\end{array}$ \\
\hline Advantages & $\begin{array}{l}\text { Assure the introduction } \\
\text { of the students within } \\
\text { the framework of } \\
\text { intellectual organized } \\
\text { work. }\end{array}$ & $\begin{array}{l}\text { Valorise possibilities, } \\
\text { resources, and local } \\
\text { researches. }\end{array}$ & $\begin{array}{l}\text { Determines the } \\
\text { sensibility at the contact } \\
\text { with the surrounding } \\
\text { environment, generating } \\
\text { an interest towards } \\
\text { knowledge. }\end{array}$ \\
\hline Disadvantages & $\begin{array}{l}\text { Predominance of } \\
\text { information upon the } \\
\text { qualitative aspects of } \\
\text { the change. }\end{array}$ & $\begin{array}{l}\text { The danger of the lowering } \\
\text { of the pedagogical, } \\
\text { scientific and formative } \\
\text { value; the absence of } \\
\text { some evaluative systemic } \\
\text { actions. }\end{array}$ & $\begin{array}{l}\text { Creation of a conflict } \\
\text { having educational, } \\
\text { moral and esthetical } \\
\text { finalities. }\end{array}$ \\
\hline
\end{tabular}

(Melnic\&Botez, 2014)

\subsection{The Connection between Living Heritage and Education}

Knowledge and learning are humanity's greatest reasonable renewable resources to react to challenges and create alternatives. Education does more than respond to a developing world. In other terms, education transforms lives and the world.

The primary purpose of education is to lead civilization into the community. If education failed in leading about enhancement and well-being, then it is recognized to be useless. Education was the most effective instrument in leading the changes within an individual. Education assimilates an individual to preserves, transmits, and develops the living heritage of the community. The relationship between education and living heritage is imperishable because education and living heritage are mutually dependent, integral, and supplementary in all aspects and activities.

Living Heritage plays an imperative role in man's life. The appreciation of living heritage can guidance an individual in adapting to the natural and social environment, cultivate an individual's personality, socialization of the individual, appropriate use of freedom, and considerate other living heritages' improper meaning - the education and living heritage transmitted to an individual through their families, communities, and educational institutions. Taking into consideration the importance of living heritage and the role played by education in the socialization and the acculturation of an individual, it is essential to interpret the changes that have taken shape in our living heritage. 


\subsubsection{Cultural Educational for school}

Most cultural-educational institutes around the world founded on European models. In many countries, it was the settlers or conquerors that introduced formal education. With such a turbulent history, indigenous peoples find difficulty engaging with educational institutes that are so foreign? The success education system for indigenous students, the students need to develop a sense of belonging. This education system documented as being an essential human need to establish belonging a people needs to find commonalities with their own life and living situation that similarity with their context.

The new education institutes were developed in many countries around the world to transmitted living heritage. The educational framework begins with pre-school and primary schools through the nation's education body to teach the cultural practice in their curriculum. The education system focused on early childhood education until the secondary level. The results showed the many successes of these schools. The tertiary education sector presents to seek to find common ground with both living heritage and education in the education system. The universities approach offered a qualification in a particular aspect of cultural practice to create more separatism rather than belonging. But many tertiary education institutes are doing very little, in particular, to offer technical training and apprenticeships in this area. These institutes must begin to include cultural practice were suitable in this age group learning before the introduction of total immersion and charter schools. By using language as a basis, the simple as learning traditional greetings, naming objects, counting, and learning songs can all bring to potent discussions and learning about living heritage. Living heritage and communication go hand in hand, so when teaching language, you must cover many aspects of the living heritage.

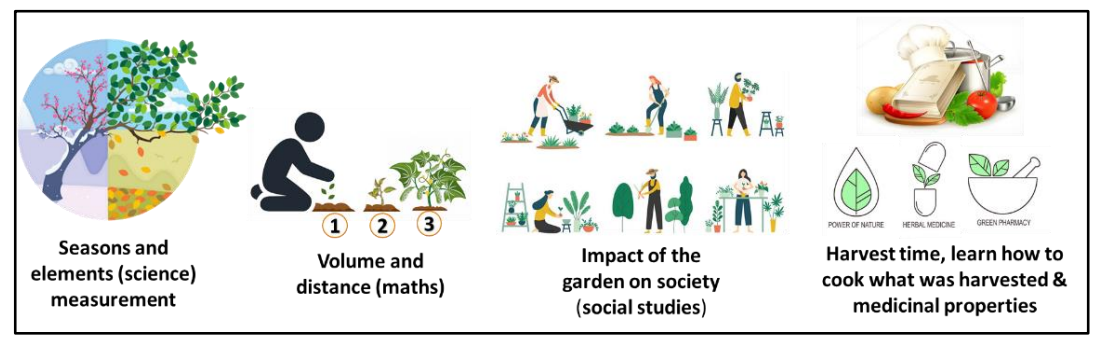

Figure 3: Integrated learning in traditional gardening (living heritage) at a charter school in Hawaii.

"Integrative learning defined as a connecting skill and knowledge from multiple sources and experiences that applying theory to practice in various settings, utilizing diverse and even contradictory points of view, and understanding issues and positions contextually." (Huber et al., 2005). Integrated learning in a charter school in Hawaii was used successfully with studying traditional gardening (living heritage). In figure 3 showed students learned about the seasons and elements (science) measurement, volume, and distance (maths) 
and the impact of the garden on society (social studies). Students also learned how to cook what they harvested and learn about the medicinal properties of some plants. In this single topic, students experienced a range of learning modalities and drew on many different sources of knowledge. This approach was a success from the level of engagement and understanding of the students. Collaboration Learning helps to develop learning communities within classes and institutions (Laal \&Ghodsi, 2012; Tinto, V., 1997).

Heritage Education highlights 2017 in Singapore on Pre-school and Primary and Secondary and Tertiary as part of the heritage education in the life cycle approach (Singapore National Heritage Board, 2017). These programs will give opportunity and accompany every student to learn about Singapore's culture and heritage at various stages of their academic journey. Singapore museums and institutions offered multiple events and activities in living heritage. In table 2 represent the examples of events and activities.

Table 2: The example of events and activities offered by Singapore museums and institutions.

\begin{tabular}{|c|c|c|c|c|c|}
\hline Program & Age & $\begin{array}{c}\text { Day \& } \\
\text { Duration }\end{array}$ & $\begin{array}{l}\text { Museums/ } \\
\text { Institutions }\end{array}$ & Fees & Activities \\
\hline \multicolumn{6}{|c|}{ Pre-school and Primary } \\
\hline $\begin{array}{l}\text { STAMPS! } \\
\text { STAMPS! } \\
\text { STAMPS! }\end{array}$ & 4 years old & $\begin{array}{l}\text { Mondays to } \\
\text { Fridays } \\
\text { (1 hour) }\end{array}$ & $\begin{array}{l}\text { Singapore } \\
\text { Philatelic } \\
\text { Museum }\end{array}$ & $\begin{array}{l}\$ 7.00 \\
\text { per } \\
\text { min } 10 \\
\text { pax }\end{array}$ & 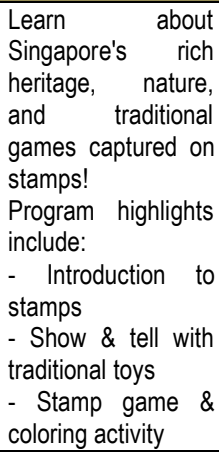 \\
\hline $\begin{array}{l}\text { THE WORLD } \\
\text { OF STAMPS }\end{array}$ & $\begin{array}{l}5-6 \text { years } \\
\text { old }\end{array}$ & $\begin{array}{l}\text { Mondays to } \\
\text { Fridays } \\
\text { (1 hour) }\end{array}$ & $\begin{array}{l}\text { Singapore } \\
\text { Philatelic } \\
\text { Museum }\end{array}$ & $\begin{array}{l}\$ 7.00 \\
\text { per pax, } \\
\min 15 \\
\text { pax }\end{array}$ & $\begin{array}{l}\text { Learn about } \\
\text { Singapore's } \\
\text { heritage, } \\
\text { transportation, } \\
\text { traditional trades, } \\
\text { games, and } \\
\text { significant events, } \\
\text { which captured on } \\
\text { stamps at the } \\
\text { Singapore Philatelic } \\
\text { Museum. } \\
\text { Program highlights: } \\
\text { - Learn about the } \\
\text { different parts of a } \\
\text { stamp to remove } \\
\text { - Learn to } \\
\text { stamps from an } \\
\text { envelope }\end{array}$ \\
\hline
\end{tabular}




\begin{tabular}{|c|c|c|c|c|c|}
\hline & & & & & $\begin{array}{l}\text { - Complete a fun } \\
\text { worksheet }\end{array}$ \\
\hline $\begin{array}{l}\text { COLOURFUL } \\
\text { WORLD } \\
\text { OF STAMPS }\end{array}$ & $\begin{array}{l}7 \text { - } 8 \text { years } \\
\text { old }\end{array}$ & $\begin{array}{l}\text { Mondays to } \\
\text { Fridays } \\
(1 \mathrm{~h} \mathrm{30m})\end{array}$ & $\begin{array}{l}\text { Singapore } \\
\text { Philatelic } \\
\text { Museum }\end{array}$ & $\begin{array}{l}7.00 \\
\text { per } \\
\text { min } 15 \\
\text { pax }\end{array}$ & $\begin{array}{l}\text { Learn "The } \\
\text { Colourful World of } \\
\text { Stamps" on a } \\
\text { guided tour of the } \\
\text { museum and } \\
\text { discover that } \\
\text { stamps are } \\
\text { miniature } \\
\text { ambassadors that } \\
\text { document our } \\
\text { historical } \\
\text { milestones, } \\
\text { inspirations, } \\
\text { national } \\
\text { achievements, and } \\
\text { more. Students will } \\
\text { experience } \\
\text { design their own } \\
\text { stamps and share } \\
\text { them with their } \\
\text { classmates. }\end{array}$ \\
\hline $\begin{array}{l}\text { SELF-GUIDED } \\
\text { TOUR: } \\
\text { CHASING } \\
\text { BIBIK NEO }\end{array}$ & $\begin{array}{l}7-9 \text { years } \\
\text { old }\end{array}$ & $\begin{array}{l}\text { Mondays to } \\
\text { Fridays } \\
10 a m-12 p m \text {, } \\
12 p m-2 p m, \\
2 p m-4 p m\end{array}$ & $\begin{array}{l}\text { Peranakan } \\
\text { Museum }\end{array}$ & & $\begin{array}{l}\text { Learn about the } \\
\text { mysterious Bibik } \\
\text { Neo, the matriarch } \\
\text { of a Peranakan } \\
\text { household, while } \\
\text { tracking down the } \\
\text { clues entrenched in } \\
\text { objects throughout } \\
\text { the galleries. }\end{array}$ \\
\hline $\begin{array}{l}\text { TALES OF OLD } \\
\text { SINGAPORE: } \\
\text { AN } \\
\text { INTERACTIVE } \\
\text { TOUR }\end{array}$ & $\begin{array}{l}7 \text { - } 12 \text { years } \\
\text { old }\end{array}$ & $\begin{array}{l}\text { Tuesdays to } \\
\text { Thursdays } \\
\text { (2h) }\end{array}$ & $\begin{array}{l}\text { National } \\
\text { Museum of } \\
\text { Singapore }\end{array}$ & $\$ 16.00$ & 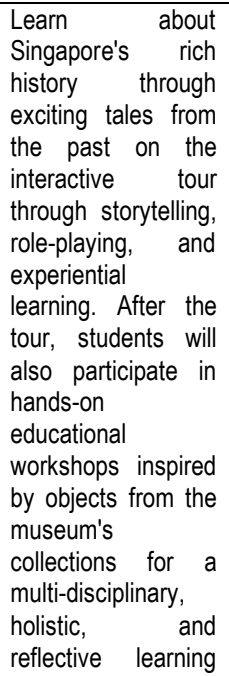 \\
\hline
\end{tabular}




\begin{tabular}{|c|c|c|c|c|c|}
\hline & \multicolumn{4}{|c|}{ Secondary and Tertiary } & experience. \\
\hline $\begin{array}{l}\text { SINGAPORE } \\
\text { HISTORY } \\
\text { WORKSHOP: } \\
\text { CROWN } \\
\text { COLONY }\end{array}$ & $\begin{array}{l}13-14 \text { years } \\
\text { old }\end{array}$ & $\begin{array}{l}\text { Tuesdays to } \\
\text { Thursdays } \\
\text { (2h) }\end{array}$ & $\begin{array}{l}\text { National } \\
\text { Museum of } \\
\text { Singapore }\end{array}$ & $\$ 18.00$ & $\begin{array}{l}\text { This workshop } \\
\text { encourages } \\
\text { students to learn to } \\
\text { discover and } \\
\text { appreciater how } \\
\text { individuals and } \\
\text { communities helped } \\
\text { Singapore during } \\
\text { the colonial era } \\
\text { (1819-1942) to } \\
\text { become a bustling } \\
\text { entrepot. The } \\
\text { student will join the } \\
\text { special guided tour } \\
\text { of the Crown } \\
\text { Colony section of } \\
\text { the Singapore } \\
\text { History Gallery, } \\
\text { engaged in thought- } \\
\text { provoking } \\
\text { discussions, hands- } \\
\text { on activities, and } \\
\text { quizzes. }\end{array}$ \\
\hline $\begin{array}{l}\text { NATIONAL } \\
\text { STAMP } \\
\text { COLLECTING } \\
\text { COMPETITION } \\
\text { WORKSHOP }\end{array}$ & $\begin{array}{l}13 \text { - } 16 \text { years } \\
\text { old }\end{array}$ & $\begin{array}{l}\text { Mondays to } \\
\text { Fridays } \\
\text { (2h) }\end{array}$ & $\begin{array}{l}\text { Singapore } \\
\text { Philatelic } \\
\text { Museum }\end{array}$ & $\begin{array}{l}\$ 4.00 \\
\text { per pax }\end{array}$ & $\begin{array}{l}\text { The students using } \\
\text { stamp products and } \\
\text { narratives based on } \\
\text { a theme choice } \\
\text { (e.g., nature, } \\
\text { transportation, } \\
\text { sports, culture, etc.) } \\
\text { and work in groups } \\
\text { of } 4 \text { people and } \\
\text { create a philatelic } \\
\text { exhibition. The } \\
\text { students will gain } \\
\text { knowledge on how } \\
\text { to present their } \\
\text { exhibits for the } \\
\text { National Stamp } \\
\text { Collecting } \\
\text { Competition at the } \\
\text { workshop. }\end{array}$ \\
\hline $\begin{array}{l}\text { GUIDED TOUR: } \\
\text { CROSS- } \\
\text { CULTURAL } \\
\text { ART\# }\end{array}$ & $\begin{array}{l}13 \text { - } 17 \text { years } \\
\text { old } \\
\text { JC, Poly, } \\
\text { Uni } \\
17 \text { - } 24 \text { years } \\
\text { old }\end{array}$ & $\begin{array}{l}\text { Mondays to } \\
\text { Fridays } \\
\text { 10am-12pm, } \\
\text { 12pm-2pm, } \\
2 \mathrm{pm}-4 \mathrm{pm}\end{array}$ & $\begin{array}{l}\text { Asian } \\
\text { Civilisations } \\
\text { Museum }\end{array}$ & & $\begin{array}{l}\text { Find the } \\
\text { connections } \\
\text { between the diverse } \\
\text { culture of Asia and } \\
\text { how the trade, } \\
\text { interactions, and } \\
\text { exchange of ideas } \\
\text { have affected art in } \\
\text { Asia. }\end{array}$ \\
\hline
\end{tabular}




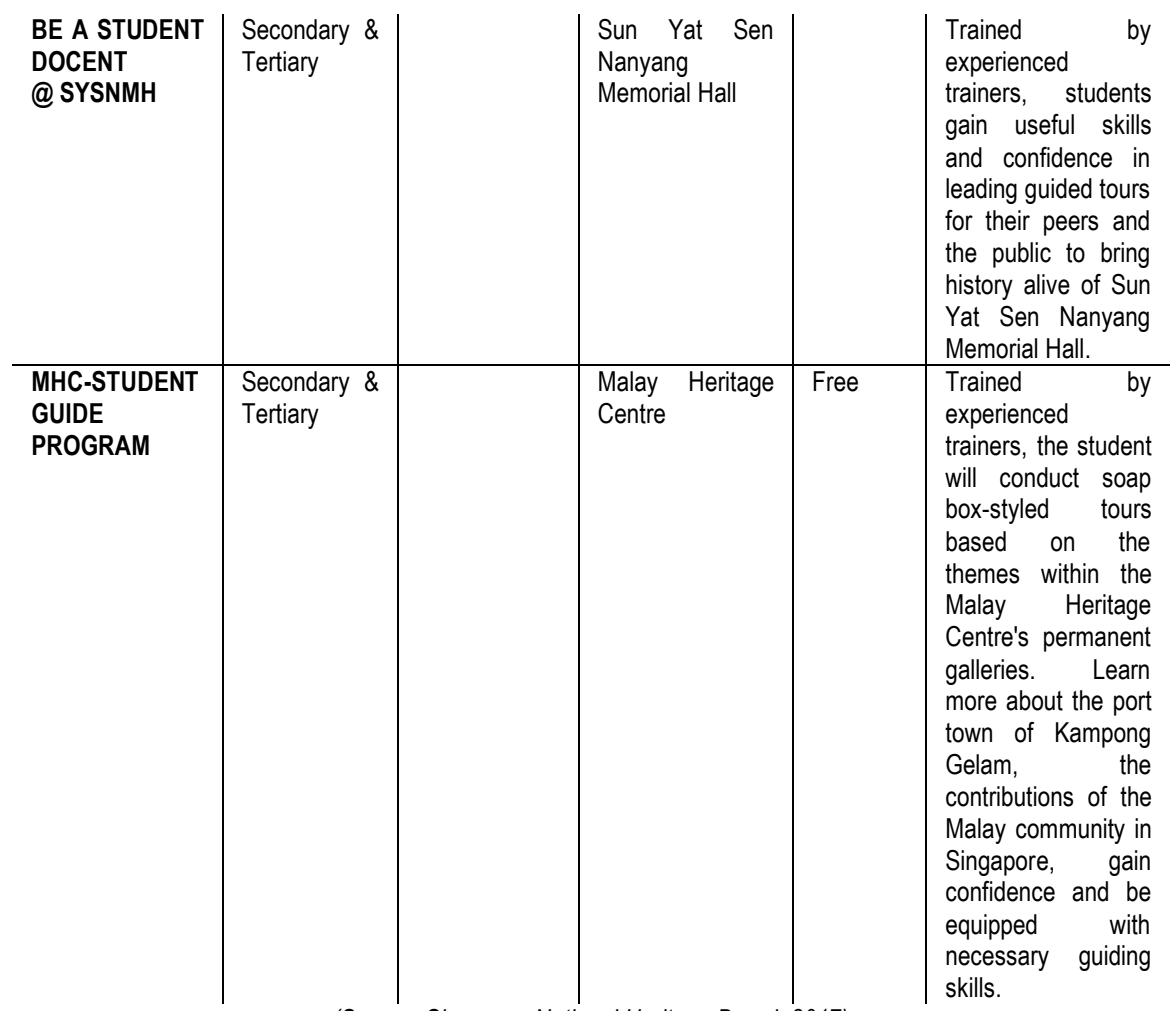

(Source: Singapore National Heritage Board, 2017)

\subsubsection{The School of Living Traditions}

The School of Living Traditions (SLTs), as a flagship project of NCCA, is initiated by the sub commission on Cultural Communities and Traditional Arts toward the safeguarding of traditional cultures and practices through the transfer of indigenous knowledge and skills to the young people by the cultural masters in the community. The SLTs a model that is being adopted by the different agencies and institutions to safeguard cultural heritage but also for the advocacy for the reinvigoration of indigenous knowledge systems as well as for the recognition of cultural rights (Talavera, 2015).

Besides being a form of safeguarding measure, the SLT now channeled to promote the 2003 convention and its implementation through the project proposed by the International Research Centre for Intangible Cultural Heritage in the Asia-Pacific Region (IRCI), i.e., one of the category two centers of UNESCO. Its envisioned to be an integrated and interagency development intervention involving cultural communities and multi-sectoral stakeholders as well as local government units and assisting government agencies. Education for sustainable development, including gender equality and human rights, is 
mainstreamed at all levels in a) national education policies, b) curricula, c) teacher education, and, d) student assessment.

A guide for facilitators and coordinators for a School of Living Traditions on Buklog Thanksgiving Ritual of the Subanen in the Philippine was done in 2019 by the International Research Centre for ICH in Asia-Pacific Region, under the auspices of UNESCO, and the National Commission for Culture and the Arts. This learning guide comprises two parts, 1) the context of the Buklog, a vital ICH element of the Subanen people, and 2) provides a collection of learning modules related to the Buklog. In figure 4 represented the five samples of SLT Learning Modules for a School of Living Traditions on Buklog Thanksgiving Ritual of the Subanen was provided based on five board 'domains' in Intangible Cultural Heritage.

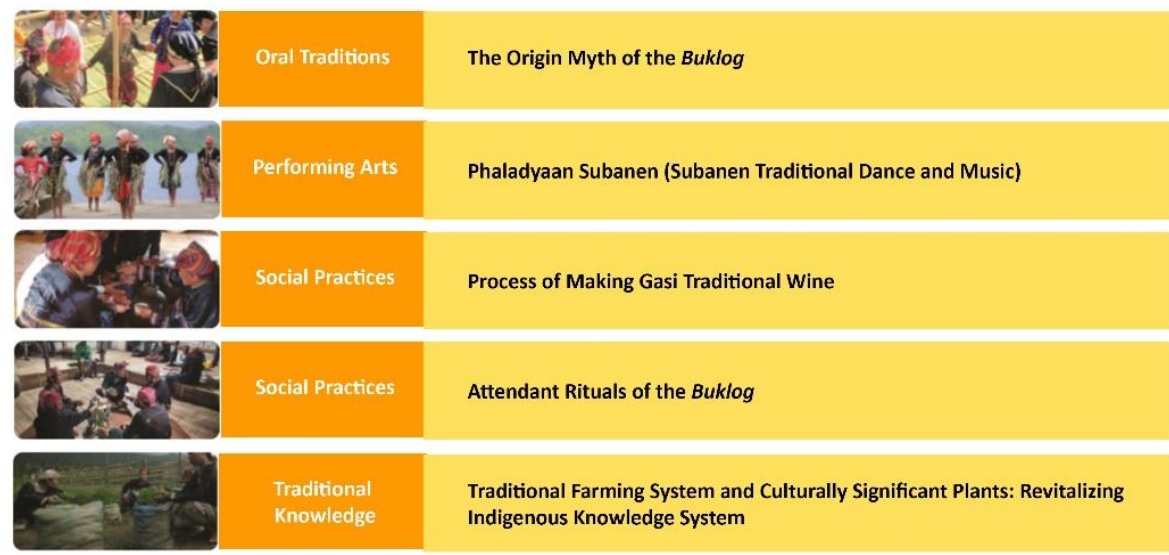

Figure 4: The 5 samples of SLT Learning Modules for a School of Living Traditions on Buklog Thanksgiving Ritual of the Subanen.

\subsection{The significance of Living Heritage Conservation Education for the Community}

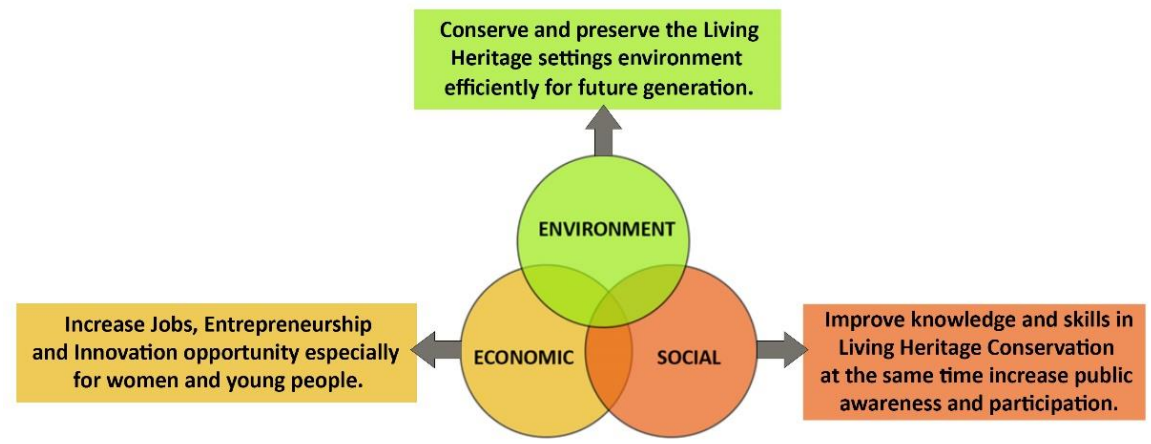

Figure 5: The significance of Living Heritage Conservation Education for the Community. 
Safeguarding $\mathrm{ICH}$ can efficiently contribute to sustainable development in the economic, social, and environment and also contributing to peace and security. Education is the most excellent tool for transmitted living heritage or $\mathrm{ICH}$ practices of local people and the community. In figure 5 showed the significance of Living Heritage Conservation Education for the community.

\subsection{Conclusion \& Recommendations}

In conclusion, the key a quality education of living heritage education conservation for the community not only fulfills people's needs but also helps link and empower both local people and the community to conserve the living heritage effectively and at the same time increase public awareness and participation. This study provides the Community-Based Education (CBE) Framework for Living Heritage Conservation and Its Participation Level toward Sustainable Development at World Heritage Site in Malaysia as the new direction for further research.

\section{Acknowledgement}

Fundamental Research Grant Scheme supported this study under the Ministry of Higher Education Malaysia (FRGS/1/2019/WAB04/UPM/02/2). The authors would like to thank Universiti Putra Malaysia for their support.

\section{References}

Hani, U. et al. (2012). Preserving Cultural Heritage through Creative Industry: A lesson from SaungAngklungUdjo. Procedia - Economics and Finance, 4, p. 193 - 200.

Huber, Mary Taylor, Pat Hutchings, and Lee S. Shulman (2005). The scholarship of teaching and learning today. In encouraging multiple forms of scholarship: Voices from the Field, ed. Kerry Ann O'Meara and R. Eugene Rice. Washington, DC: American Association for Higher Education. Forthcoming.

Laal, M. \&Ghodsi, S. M. (2012). Benefits of collaborative learning. Journal of Social and Behavioral Sciences, 31(2012), p. $486-490$.

Lenzerini, F. (2011).Intangible Cultural Heritage: The Living Culture of Peoples. The European Journal of International Law, 22(1), p. 101 - 120.doi: 10.1093/ejil/chr006

Melnic, A., \&Botez, N. (2014). Formal, Non-Formal and Informal Interdependence in Education. Journal of Economy Transdisciplinarity Cognition, vol. 17 (1), p. 113 -118. www.ugb.ro/etc

MohdBaroldin, N., \&Mohd Din, S.A. (2018). Conservation Planning Guidelines and Design of Melaka Heritage Shophouses. Asian Journal of Environment - Behaviour Studies (ajE - Bs), 3(8), May / Jun 2018 (p.61-70).

Singapore National Heritage Board (2017).Heritage Education Highlights 2017. www.nhb.gov.sg 
Abdul Aziz, N.A., et.al. / Asian Journal of Quality of Lie (AjQoL) 5(18), Jan/Apr 2020 (pp.43-56)

Tinto, V. (1997). Enhancing learning via the community. Journal of Thought and Action, 6 (1), p. 53 - 54.

The International Research Centre for ICH in Asia-Pacific Region, under the auspices of UNESCO, and the National Commission for Culture and the Arts (2019). Multi-Disciplinary Study on Intangible Cultural Heritage's Contribution to Sustainable Development, Focusing on Education: A Guide for Facilitators and Local Coordinators for a School a Living Traditions on Buklog of Thanksgiving Ritual of the Subanen, Philippines.

UESCO (2003). Conclusions and Recommendations of the Conference Linking Universal and Local Values: Managing a Sustainable Future for World Heritage. Amsterdam: UNESCO World Heritage Centre.

UNESCO (2019). Culture 2030 Indicators. The United Nations Educational, Scientific and Cultural Organization, 7 , place de Fontenoy, 75352 Paris 07 SP, France. ISBN 978-92-3-100355-4

Ujang, N. (2017). Place Attachment and Continuity of Urban Place Identity. Asian Journal of Environment Behaviour Studies, ajE - Bs, 2(2), p. 117 - 132. 